Caries Res. 1980;14:I-VI

\title{
Contents, Vol. 14, 1980
}

\section{No. 1}

Original Paper

Effects of Pyridoxine, Phytate and Invert Sugar on Plaque Composition and Caries Activity in the Monkey (Macacafascicularisi

Cole, M.F.;Eastoe, J.E.; Curtis, M.A.; Korts,D.C, and Bowen,W.H 1

Effect of Xylitol-Supplemented Diets on the Progression and Regression of Fissure Caries in the Albino Rat

Leach, S.A. and Green, R. M 16

Inhibition by Sodium Fluoride of 3H-Glycerol Incorporation into Lipoteichoic Acid in

Streptococcus mutans

Ciardi, J.E.;Reilly, J.A, and Bowen,W.H 24

Enhancement of Fluoride Effectiveness by Experimental Cariogenic Priming of Human Enamel

Kolourides,T.; Keller, S.E.; Manson-Hing, L., and Lilley, V 32

Histopathological Appearance of Caries-Like Lesions of Enamel Created Artificially in vitro in Acidified Gels Containing Fluoride

Kidd, E.A.M.andJoyston-Bechal,S 40

Histopathological Appearance of Artivicially Produced Caries-Like Lesions of Enamel Treated with APF during Lesion Formation in vitro

Joyston-Bechal, S. and Kidd, E. A. M 45

Rate of Fluorine Uptake by Surface and Subsurface Sound Enamel from Sodium

Monofluorophos-phate

Mellberg,J.R 50

Short Communication

Increased Smooth-Surface Caries Incidence in Gnotobiotic Rats Immunized with Actinumyces viscosus

Burckhardt,J.J. and Guggenheim, B 56

Announcement

27th ORCA Congress 1980, and changed instructions

60

\section{No. 2}

Original Paper

Cariogenicity of Disaccharide Alcohols in Rats

Hoeven, J.S. van der 61

Contribution of Maltilol and Lycasin ${ }^{\circledR}$ to Experimental Enamel Demineralization in the Human Mouth

Rundegren, J.; Koulourides, T., and Ericson, T

Effect of Flossing with and without Iodine, on Human Interproximal Plaque Flora

Newbrun, E.; Heilblum, R., and Mayeda, A 75

Effects of Chlorhexidine Dihydrochloride in the Diet on Caries in Hamsters

Gaffar, A. and Marcussen, H.W 84 
A Nondestructive Method for Monitoring De- and Remineralization of Enamel

Bosch, J.J. ten; Borsboom, P.C.F., and Cate,J.M. ten

90

Absorption of Fluoride from Fluoride Dentifrices

Ekstrand, J. and Ehrnebo, M 96

IV

Contents

In vivo Uptake and Retention of Fluoride in Human Surface Enamel after Application of a

Fluoride-Containing Lacquer (Fluor Protector ${ }^{\circledR}$ )

Bruun, C; Givskov, H., and Stoltze, K 103

Calorimetric Studies of the Interaction between Hydroxyapatite and Certain Anions in Aqueous

Solution

Benton, D.P.; Bullock, J.I.; Danil de Namor, A.F., and Ingram, G.S 110

Penetration of Fluorine from Sodium Monofluorophosphate into Artificially Produced Incipient

Enamel Lesions

Mellberg,J.R 115

No. 3

Original Paper

Variable Ratios of Lactate and Malate Dehydrogenase-Like Enzyme Activities and LDH

Isoenzyme Distribution in the Odontoblast-Predentine Region of Intact and Carious Human

Teeth

Karjalainen, S. and Mäkinen, K.K 121

Effects of the Topical Application of Mutanase on Rat Caries

Guggenheim, B.; Regolati†, B.; Schmid, R., and Mühlemann, H.R 129

Cariogenicity of Topically Applied Sugar Substitutes in Rats under Restricted Feeding

Conditions

Hefti,A $\quad 137$

Dental Caries and the Concentration of Aluminium and Strontium in Enamel

Vrbic, V. andStupar,J 142

Abstracts

Abstracts of Papers Presented at the 26th ORC A Congress, June 28 to 30, 1979,

Stirling, Scotland 149

Announcement

Symposium in Utrecht, June 19, 1980

No. 4

Original Paper

Plasma Fluoride Concentration and Urinary Fluoride Excretion in Children following

Application of the Fluoride-Containing Varnish Duraphat ${ }^{\circledR}$

Ekstrand,J.; Koch, G., and Petersson, L.G 185

Lesion Depth and Microhardness Indentations on Artificial White Spot Lesions

Arends, J.; Schuthof, J., and Jongebloed, W.G 190

Influence of Fluoride in Surface Enamel and Degree of Dental Fluorosis on Caries Development in vitro

Kidd, E.A.M.; Thylstrup, A.; Fejerskov, O., and Bruun, C 196

A Method for Simultaneous Measurement of Calcium and Phosphorus in Tooth Surface

Samples, Dissolved in vivo, Using Activation Analysis

Feasey, CM.; MacFadyen, E.E.; Gillespie, F.C., and Stephen, K.W 203 
Chemical Studies of the Protective Action of Phosphate Compounds against the Demineralization of Human Dental Enamel in vitro

Grenby,T.H. and Bull, J.M 210

Use of High-Performance Liquid Chromatography Techniques to Study the Protection of

Hydroxylapatite by Fluoride and Glycerophosphate against Demineralization in vitro

Grenby,T.H. and Bull, J.M 221

Contents

$\mathrm{V}$

Short Communications

Plasma Alkaline Phosphatase Levels in Subjects Taking Fluoride Tablets

Ferguson, D.B. and Stephen, K.W 233

High Amounts of Lipoteichoic Acid in Sucrose-Induced Plaque in vivo

Rølla, G.;Oppermann, R.V.; Bowen, W.H.; Ciardi, J.E., and Knox, K.W

No. 5

Original Paper

Metabolism of Glucosylsucrose and Maltosylsucrose by Streptococcus mutans

Yamada, T.; Kimura, S., and Igarashi, K 239

Phosphorus Translocation between Enamel and Streptococcus mutans in the Presence of Sucrose and Fluoride with Observations on the Acid Phosphatase of S. mutans

Luoma, $\mathrm{H} \quad 248$

Salivary Agglutinins Tested against Streptococcus mutans

Everhart, D.L.; Shreck, M., and Seltzer, N 258

Adenosine Triphosphate Content of Human Dental Plaque as a Measure of Viable Cell Mass

Distler, W.; Kröncke, A., and Maurer, G 265

Peroxidase-Catalyzed Hypothiocyanite Production in Human Salivary Sediment in Relation to

Oral Health

Tenovuo, J. and Anttonen, T 269

Invasion of Microorganisms and Some Structural Changes in Incipient Enamel Caries. A

Scanning Electron Microscopic Investigation

Brännström, M.; Gola, G.; Nordenvall, K.J., and Torstenson, B 276

A Bacteriological Study Related to the Onset of Dental Caries in Monkeys IMacaca fasciculańs)

Colman, G. and Hayday, H 285

A Mechanism for the Anticaries Action of Fluoride

Ingram, G.S. and Nash, P.F 298

Effect of an Interruption in Water Fluoridation on the Caries Prevalence of the Primary and

Secondary Dentition

Künzel, W 304

Diffusion Inhibition as a Mechanism for the Caries-Reducing Effect of Fluoride

Verbeeck, R.M.H.; Driessens, F.C.M.; Schaeken, H.G., and Heijligers, H.J.M 311

Fluoride Uptake by Enamel Surfaces, Root Surfaces and Cavity Walls following Application of a

Fluoride Varnish in vitro

Tveit, A.B 315

The Effects of Topical Applications of Sugar Substitutes on the Incidence of Caries and Bacterial Agglomerate Formation in Rats

Firestone, A.R.; Schmid, R., and Mühlemann, H.R 324 
Surface Roughness of Acid-Etched and Demineralized Bovine Enamel Measured by a Laser Speckle Method

Groenhuis, R.A.J.; Jongebloed, W.L., and Bosh, J.J. ten 333

Pre- and Posteruptive Effects of Low Doses of Strontium on Dental Caries in the Rat

Ashrafi, M.H.; Spector, P.C., and Curzon, M.E.J 341

Short Communication

Changes in Neutral Protease Activity in Human Tooth Pulp during Health and Disease

Le Bell, Y 347

Announcement $\quad 350$

VI Contents

No. 6

Original Paper

Remineralization of Artificial Enamel Lesions in vitro. III. A Study of the Deposition

Mechanism

Cate, J.M. ten and Arends, J 351

Microradiographic Observation of Acidic Subsurface Decalcification in Synthetic Apaptite

Aggregates

Langdon, D.J.; Elliott, J.C., and Fearnhead, R.W 359

Ultrastructure of the Human Odontoblast Process and Its Mineralisation during Dental Caries

Frank, R.M. and Voegel,J.C 367

Morphology of Outer Regions of Fluorosed Human Deciduous Enamel

Sundström, B.; Arends, J.; Jongebloed, W.L., and Bouchouchi, M 381

Pattern of Mineral Uptake on Developing Bovine Incisors

Robinson, C; Weatherell, J.A.; El-Attar, I., and Deutsch, D 389

Phosphate Diffusion in Whole Bovine Enamel at $\mathrm{pH} 7$

Rooij, J.F. de; Kolar, Z., and Arends, J 393

Fluoride Uptake in Enamel. In vitro Comparison of Topical Agents

Arends, J.; Lodding, A., and Petersson, L.G 403

Artificial Caries-Like Lesions around Conventional, Fluoride-Containing and Dispersed

Amalgams

Heintze, U. and Mörnstad, H 414

Effect of Some Polyvalent Cations on the Acidogenicity of Dental Plaque in vivo

Oppermann, R.V. and Rölla, G 422

Topographical Relationship between Plaque and Approximal Caries

Newman, H.N. and Morgan, W.J 428

A Gnotobiotic Study to Distinguish between Heredity and the Oral Micronora as Transmitters of

Dental Caries Activity in Laboratory Rats

Grenby,T.H. and Owen, D 434

Cariogenicity of Glucose, Sucrose and Amylopectin in Rats and Hamsters Infected and

Noninfected with Streptococcus mutans

Birkhed, D.; Frostell. G., and Lamm, C.J 441

Short Communication

Use of Ultraviolet Light in Early Detection of Smooth Surface Carious Lesions in Rats

Shrestha, B.M 448

Announcement

28th ORCA Congress 1981, and changed instructions 
Author Index 454

Subject Index 457 